\title{
Delayed IT Usage: \\ Is It Really the Drag on Europe's Productivity?
}

\author{
Francesco Daveri*
}

\begin{abstract}
This paper explores the quantitative plausibility of three candidate explanations for the European productivity slowdown with respect to the US. The empirical plausibility of the common wisdom on the topic (the "IT usage" hypothesis) is found to crucially depend on how IT-using industries are defined. If a narrow definition is chosen, the IT usage hypothesis no longer explains the whole of the EU productivity slowdown but just about 55 percent of it, with the remaining part to be attributed to other factors than IT, as argued in the "IT irrelevance" view. No room is left for IT-producing industries as another potential vehicle for the US-EU productivity growth gap, instead. (JEL O4, $\mathrm{O} 47, \mathrm{O} 52)$
\end{abstract}

\section{Introduction}

"With aggregate evidence showing that countries in Europe invest less in ICT and this new evidence that intensive ICT users have shown slower productivity growth in Europe, it appears that the slower diffusion of ICT is the principal factor in explaining the lower European productivity growth" (van Ark, Inklaar and McGuckin 2003b, 297)

The current productivity slowdown in Europe has been an issue of concern for scholars and policy-makers for a long time now. The slowing down of productivity growth is a reason for concern in itself, for productivity growth is the ultimate engine of growth in living standards. Yet a decline of about half a percentage point per year - such is the approximate entity of the growth slowdown of Europe's business sector - would not have gained news headlines, had this not taken place in parallel with the productivity acceleration experienced by the US economy since the second half of the 1990s. Europe may not be facing decline (yet), but it has seemingly lost an opportunity to grow faster.

Today's common wisdom on the causes of the EU productivity problems comes in three steps. First, the EU growth gap with the US is attributed to a

* Università di Parma, and IGIER, francesco.daveri@unipr.it.

This paper draws on previous work for a CEPS Report on the causes of the productivity slowdown in Europe, conducted on behalf of the European Parliament. I am thankful to the Managing Editor and three referees of this Journal, seminar participants at LBS and Carlos III (Departamento de Economia de Empresa), as well as Daniel Gros for many useful comments on previous drafts, and to Federico De Francesco for his dedicated research assistance.

(C) Ifo Institute for Economic Research, Munich, 2004 
few business sector services, such as wholesale trade, retail trade and financial intermediation. Second, these industries are classified among those intensively using information and communication technologies (IT, from here onwards). Third - implied by the first two - Europe's productivity problem is said to essentially stem from delayed IT usage. Such a view (labeled the "IT usage hypothesis" from here onwards) is well exemplified in the quote of van Ark, Inklaar and McGuckin (2003b) at the top of this page, but is also shared by other studies, and notably by the detailed cross-country study undertaken by McKinsey Global Institute (1997; 2002). Blanchard (2003), in his recollection of the main facts of European growth, may also be seen as sympathetic with such a view.

As any other one-sided view, this may have gone too far. In this paper, the productivity growth gap between the US and the EU (defined as the difference between the changes in the growth rates of labor productivity in the US and the $\mathrm{EU})$ is decomposed at the industry level in three components, each representative of a different view. In addition to the IT usage view, Gordon's "IT production" view and a residual view labeled "IT irrelevance" hypothesis (implying that IT was simply not the engine of the growth gap) are scrutinized. This is done employing the latest version of the data set constructed at the Groningen Growth and Development Center (GGDC), now freely downloadable at: www.ggdc.nl. These data are still being updated, but have already served as a background for many papers, the most recent of which are collected in O'Mahony and van Ark (2003). It is the best data set currently available as far as industry data are concerned.

The experiments of industry accounting presented here provide a numerical rendition of the various views. The key result of the paper is that the common wisdom explains a large fraction of the US-EU growth gap, but not as much as assumed by its proponents. The explanatory power of the "IT usage" hypothesis in fact crucially hinges on the researcher's decision on how to classify individual industries in one industry group or another, the alternatives being IT producers, IT users, or non-IT related industries. Previous studies have granted an "ITusing" status to the top 50 percent industries in an industry ranking based on the value added shares of IT services in the US economy. In this way, a few fast-growing industries (such as retail trade and other smaller manufacturing industries) have been controversially assigned to the group of the "IT-using" industries. This classification procedure exaggerates the explanatory power of the IT-usage hypothesis, at the expense of the explanatory power of the "IT irrelevance" view. An alternative classification of industries (which identifies as "IT users" only those industries with above-average, rather than abovemedian, IT capital services) indeed provides a more balanced picture and unveils that the IT usage hypothesis may explain as much as 55 percent of the 
growth gap, with another 45 percent explained by the "IT irrelevance" view. No explanatory power is instead left for growth gaps among IT-producing industries.

The issues discussed here are not an academic curiosum, but bear immediate policy relevance. If the IT usage hypothesis is true, then the European Commission and the EU national Governments may continue tracking IT diffusion as an intermediate policy target as they are currently doing under the Lisbon Strategy. If, instead, IT diffusion is not the ultimate (or the only) engine of innovation and productivity growth, destination of public funds need not be skewed in favor of IT.

The paper's structure is as follows. In Section 2, a brief recap of the main facts on the post-1995 Europe's productivity slowdown and IT diffusion is presented. In Section 3, the three main explanations of such slowdown are set out. In Section 4, such explanations are quantitatively evaluated within a standard industry growth accounting framework. In Section 5, conclusions are drawn.

\section{The facts about productivity and IT in Europe}

\subsection{The productivity slowdown in Europe}

Around 1995, something happened in the US economy, which triggered a marked rise in the growth rate of labor productivity (from some 1.2 to 2.3 percent per year) with respect to the former twenty five years average. In parallel, the growth rate of value added per man hour declined to some 1.5 percent per year in the European Union. This is about one percentage point lower than in 1980-1995, one third as much as the 1970s growth rate and a bare one fourth of the stellar 6 percent averaged in the same countries in the 1960s.

Table 1 reports the growth rates of value added per hour worked for the European Union and the United States, as well as the individual EU countries, distinguished in two groups ("big countries" and "small countries"), in the 1980, the first and the second half of the 1990s through 2001. Although this is a rather imperfect indicator of labor productivity ${ }^{1}$, looking at the behavior of value added per hour is a good starting point anyway.

Table 1 helps concisely describe the extent of today's productivity problem in Europe. It also shows some of the discrepancies plaguing the current debate

1 The OECD Productivity Manual (2001) provides a full-fledged and accessible discussion of productivity measurement issues. The main measurement problem stems from the inclusion of non-market services - where productivity is hard to measure - in the calculation of GDP. 
about productivity growth. The first two lines in Table 1 are from the latest OECD Economic Outlook and show the US productivity acceleration of about 0.7 percentage points and the parallel EU slowdown of about 0.9 percentage point in the last few years. Similar trends can be observed from the O'Mahonyvan Ark data set, although the computed US acceleration is somewhat bigger and the computed EU slowdown somewhat smaller than with the OECD data.

Table 1

Growth of GDP per hour worked in the EU and the US, 1980-2002

\begin{tabular}{|c|c|c|c|c|c|}
\hline \multicolumn{6}{|l|}{ Total economy } \\
\hline Source: OECD & 1980-90 & 1990-02 & 1990-95 & 1995-02 & $\begin{array}{l}(1995-02) \text { mi- } \\
\text { nus (1990-95) }\end{array}$ \\
\hline European Union & $\begin{array}{c}2.3 \\
(\mathrm{EU} 11)\end{array}$ & $\begin{array}{c}1.9 \\
\text { (EU11, EU13) }\end{array}$ & $\begin{array}{c}2.6 \\
(\text { EU13) }\end{array}$ & $\begin{array}{c}1.5 \\
\text { (EU13) }\end{array}$ & -1.1 \\
\hline USA & 1.4 & 1.7 & 1.2 & 2.0 & +0.8 \\
\hline EU minus $U S A$ & +0.9 & +0.2 & +1.4 & -0.5 & -1.9 \\
\hline $\begin{array}{l}\text { Source: } \\
\text { O’Mahony-van } \\
\text { Ark }\end{array}$ & 1979-90 & 1990-95 & & 1995-01 & $\begin{array}{l}(1995-01) \text { mi- } \\
\text { nus }(1990-95)\end{array}$ \\
\hline European Union & $\begin{array}{c}2.3 \\
(\mathrm{EU} 15)\end{array}$ & $\begin{array}{c}2.3 \\
(\mathrm{EU} 15)\end{array}$ & & $\begin{array}{c}1.6 \\
(\text { EU15) }\end{array}$ & -0.7 \\
\hline USA & 1.3 & 1.1 & & 2.2 & +1.1 \\
\hline EU minus $U S A$ & +1.0 & +1.2 & & -0.6 & -1.8 \\
\hline \multicolumn{6}{|c|}{ OECD (O'Mahony-van Ark, if OECD unavailable: in italics) } \\
\hline & $1980-90$ & $1990-95$ & & 1995-02 & $\begin{array}{l}(1995-02) \text { minus } \\
(1990-95)\end{array}$ \\
\hline Germany & 2.1 & 3.1 & & 1.7 & -1.4 \\
\hline France & 3.0 & 1.9 & & 2.0 & +0.1 \\
\hline United Kingdom & 1.9 & 2.8 & & 2.0 & -0.8 \\
\hline Italy & 2.1 & 3.2 & & 0.7 & -2.5 \\
\hline Spain & 3.1 & 2.3 & & -0.3 & -2.6 \\
\hline Austria & 1.7 & 1.7 & & 2.3 & +0.6 \\
\hline Belgium & 2.1 & 1.8 & & 1.6 & -0.2 \\
\hline Denmark & 2.0 & 1.9 & & 1.5 & -0.4 \\
\hline Finland & 2.8 & 2.5 & & 2.8 & +0.3 \\
\hline Greece & -0.1 & 0.6 & & 3.1 & +2.5 \\
\hline Ireland & 3.8 & 3.6 & & 5.4 & +1.8 \\
\hline Netherlands & 1.9 & 1.3 & & 1.1 & -0.2 \\
\hline Portugal & 1.6 & 3.8 & & 2.3 & -1.5 \\
\hline Sweden & 1.2 & 2.1 & & 2.2 & +0.1 \\
\hline
\end{tabular}

Note: In the OECD data, the EU11 aggregate includes the EU15, with the exceptions of Luxembourg, Austria, Greece and Portugal, while the EU13 includes the EU15, with the exceptions of Luxembourg and Austria. When countries are excluded, this is for the unavailability of hours worked data.

Source: OECD Productivity Database, March and April 2004, and O'Mahony and van Ark (2003). 
The individual country picture also indicates that the slowdown is mainly but not exclusively a "big country" problem. Germany, the UK, Italy, Spain: they all exhibit declining growth rates through the 1990s, with sharply declining rates for Italy and Spain. France's productivity slowdown is very mild, instead.

In parallel, Table 1 also provides evidence on two other facts: productivity growth rates have been higher in Europe in the past and are being high in some parts of Europe today as well.

The "US first, EU then" ranking is the reverse of the ranking prevailing in 1980-95. In the 1980s, labor productivity in Europe (literally: in any country in Europe) used to grow faster than in the US, then trapped in the infamous productivity slowdown period.

Table 1 also substantiates a few of the European success stories, namely Ireland, Greece and Finland. Through a careful mix of tax-cutting and incentiveproviding policies, Ireland mainly took advantage of the outsourcing of mostly manufacturing activities originating abroad in other OECD countries. Finland and Greece, instead, prevailingly based their success on, respectively, the presence of a world-class technological leader in high-tech manufacturing such as Nokia and the rapid development of business sector services. Although the small size of these countries makes their good or excellent productivity performance not enough to counteract the continental tendency towards the productivity slowdown, their success is very instructive anyway.

Altogether, the historical growth precedents in the EU and the variety of paths towards successful growth signal a simple but very important message: it (i.e. achieving fast productivity growth) can be done.

\subsection{The IT revolution}

The United States has been experiencing very fast IT diffusion for a long time now. After all, Robert Solow's famous saying on how ubiquitous computers were in the US economy (except in the productivity statistics) dates back to a 1987 issue of the New York Review of Books - a long time ago indeed.

In Europe, IT diffusion lagged behind the United States. In 1992, when the Internet protocol had just been signed, IT spending was about 7 percent of GDP in English-speaking countries, such as the UK, the US and Canada, about twice as much as in Italy and Spain, with France and Germany somewhere in between. While overall spending in IT goods and services reportedly caught up with the US levels in most EU countries by the end of the last decade, this does not seemingly apply for the spending item most directly linked to growth: investment. Europeans have quickly made the domestic providers of cellular 
phone services rich. They have not been equally prompt in endowing their work environment with IT equipment.

As a result, as shown in Table 2, investment in IT capital goods kept lagging behind the US during the whole decade. Timmer, Ypma and van Ark (2003) gives an updated and rather complete picture of what happened to IT investment in the US and the EU countries. ${ }^{2}$ The GDP share of IT investment has been steadily growing over time in the US economy, from 3.3 percent in 1990 to 4.2 percent in 2001. Instead, the GDP share of IT investment stagnated in Europe between 1990 and 1995, before the recent rise in the late 1990s. As a result, the EU-US gap, after reaching two percentage points of GDP in 1990-95, has stayed constant at 1.6 percentage points of GDP between 1995 and 2001. The evidence in Daveri (2002) is also suggestive that the growth contributions from IT capital goods have been roughly in line with accumulation rates, thus definitely higher in the US than in Europe. ${ }^{3}$

\section{Table 2}

IT investment over GDP in the US and the EU, 1990-2001

\begin{tabular}{|l|cccc|}
\hline \% points & $\mathbf{1 9 9 0}$ & $\mathbf{1 9 9 5}$ & $\mathbf{2 0 0 1}$ & $\mathbf{( 1 9 9 5 - 0 1 ) - ( 1 9 9 0 - 9 5 )}$ \\
\hline USA & 3.3 & 3.7 & 4.2 & +0.5 \\
European Union & 2.2 & 2.1 & 2.6 & +0.3 \\
\hline
\end{tabular}

Source: Own calculations from Timmer, Ypma and van Ark (2003).

The parallel evidence on IT investment and growth contribution from IT capital concisely exemplifies what is meant by "lag in IT capital accumulation" of the EU with respect to the US. To sum up, Europe appears to have enjoyed a sort of gentle type of IT revolution, not as pronounced as in the United States, but certainly present and visible in the European aggregate data as well. This was seemingly not enough, though, to counteract the overall tendency for productivity growth in the EU to decline about at the same time when productivity growth accelerated in the US. The issue taken up in Section 3 and 4 is why this was the case.

2 This was initially documented through private data sources by Schreyer (2000) for the G-7 and Daveri (2000) for the EU-15. The private data picture was then, by and large, confirmed by Colecchia and Schreyer (2002) using national accounting data for nine OECD countries.

3 This is consistent with the idea that rates of return - at least the rates of return implied by the Jorgenson-Griliches (1967) calculation methodology - have not been too far apart across the two sides of the Atlantic Ocean. 


\section{Interpreting the facts}

Europe's productivity slowdown has attracted the attention of several scholars and magazine commentators. At least three explanations of the EU productivity slowdown have been put forward. Two of them put IT, respectively its usage and production, at the centre of the stage. A third view points to the irrelevance, or the second order importance, of IT as the ultimate engine of productivity growth, and concentrate on other factors. In what follows, they are labelled the "IT usage", "IT production" and "IT irrelevance" views of the EU productivity slowdown. In this section, they are briefly described in turn.

\subsection{The "IT usage" hypothesis}

If there is a common wisdom on the causes of the EU productivity slowdown, this is the "IT-usage" hypothesis, proposed by Kevin Stiroh and others to explain the US productivity revival and then adapted by van Ark, Inklaar and McGuckin (2003) to account for the US-EU growth gap in labor productivity.

According to this view, the fast pace of IT adoption was at the root of accelerating productivity growth in the United States. This is hard to deny, even at first sight: the spectacular productivity performance of the US economy in the last decade or so has occurred in parallel with the widespread diffusion of IT throughout the economy. The growth accounting studies due to Oliner and Sichel (2000) and Jorgenson and Stiroh (2000) - and their updates in Oliner and Sichel (2002), and Jorgenson, Ho and Stiroh (2003) - led most experts ${ }^{4}$ to conclude that the productivity revival in the US was indeed an IT story triggered by both capital deepening and enhanced TFP growth enabled by information technologies for about 80 percent of its extent.

The evidence based on aggregate data was importantly complemented at the industry level by both labor productivity evidence (Stiroh 2002; Nordhaus 2002a; 2002b) and TFP evidence (Triplett and Bosworth 2002). Stiroh, first, found evidence that IT-using manufacturing and services industries had prominently contributed to the US productivity revival, showing that, absent their contribution, there would have been no productivity acceleration at all in the US economy. This provided the basis for the IT-usage view that the productivity revival has been mostly driven by the successful adoption of IT, at least in the US economy.

4 For a long time, Gordon $(2000 ; 2003 a)$ has been the only dissenting, though successfully vocal, voice. In a recent paper, though, even Gordon (2003b) has seemingly joined the group of the new economy optimists. 
Such ideas have been taken up by Colecchia and Schreyer (2002) and van Ark, Inklaar and McGuckin (2003a; 2003b; VIM from here onwards) to explain the divergent productivity growth paths experienced by the US and the EU as a whole in the 1990s and tested against cross-country data for Europe. Data for individual EU countries and for the aggregate EU have been cleverly reconstructed on behalf of the European Commission and are now available in a CD ROM format (see O'Mahony and van Ark 2003). This involved the integration of the sketchy industry data available from the OECD STAN data set with national sources and substantial imputation of sometimes non-existent industry data into a unified accounting framework to be contrasted to the available US data. The fraction of imputed and nationally-sourced data is substantial (about 50 percent of the total).

The main conclusion in VIM (2003a), based on an earlier release of such data, is that stagnating productivity in some IT-using business sector services (finance, wholesale and retail trade) is the source of the bulk of the EU-US productivity growth gap in the 1990s. Altogether, in the VIM paper, the EU-US gap in the post-1995 changes of labor productivity growth is fully accounted for by the (missing) growth contributions of wholesale and retail trade, and, less importantly, the brokers and other financial intermediation industries.

Being such industries identified as intensive IT users - a point to be further discussed below - these findings have been taken to imply that the slower diffusion of ICT is the principal (or even the only!) cause of the lowering of productivity growth in Europe. This is clearly reminiscent of the ideas circulated by Stiroh and others with reference to the sources of productivity acceleration in the US economy.

\subsection{The "IT production" hypothesis}

In spite of its popularity and wide acceptance nowadays, the IT usage hypothesis is not the only game in town. Another possible explanation, eventually attributable to Gordon's $(2000$; 2003a) papers, is that productivity growth in the information age is not eventually driven by the pervasive diffusion of PCs, semiconductors, cellular phones and the Internet among firms, industries and households. Rather, growth gaps might be are essentially driven by the presence/absence of a few manufacturing industries or companies with a definite technological lead, such as the high-tech industries producing IT goods. This would attribute overwhelming importance to the fast development or continued fast growth of high-tech industries or firms as the main engine of growth, thereby shifting the emphasis away from the importance of technological diffusion. If hosting a technologically leading firm is of paramount importance 
for a country to gain from the new economy, this means that one should not expect the new economy to happily spread around the world embodied in the diffusion of computers and cellular phones. This is quite a different view of the potential productivity benefits entailed by the so called IT revolution.

In turn, this view echoes a long-standing debate in the economics of innovation and growth on whether a country, to be able to take off and grow fast, should become a technological leader in something, or whether the only requirement to grow is to develop and maintain an ability to export some, possibly lowtech, goods, and finance by the export proceeds the purchase of the latest technologies from abroad.

Such ideas have not been much explored with cross-country data, with two notable exceptions. Van Ark (2001) and Pilat and Lee (2001) employed the scattered and often incoherent data available from STAN for a few OECD countries. Altogether, such previous studies pinpointed that the EU-US growth gap may be partly explained by the lower growth contribution of IT-producing industries.

More recently, with their newly improved data set, VIM (2003b) provided some evidence not inconsistent with this view for the EU. Yet this finding has been clearly deemed of second-order importance by VIM, when compared to their preferred IT-usage hypothesis described above. The "IT usage" vs. "IT production" controversy has also been extensively discussed tested by Daveri and Silva (2004), using a variety of techniques and industry data for the Finnish economy (including information from input-output tables and the price deflators of investment goods). Their findings provide empirical support against the "IT usage" hypothesis: fast IT diffusion has not been seemingly behind the productivity success in Finland. Rather, productivity boomed in the industry where Nokia, the world leader in the production of cellular phones, is and in a few IT-related industries which mostly benefited from the (imported) reduction of the price of machinery and equipment and not so much from technological spillovers originating from Nokia.

\subsection{The "IT irrelevance" hypothesis}

The former sub-sections have each emphasized a different idea about the way in which IT may have been the driving force underlying the EU-US productivity growth gap. A third option exists: it might simply be the case that something else - and not IT - has caused the productivity slowdown in the EU in the late 1990s.

Even though the lower accumulation rates of IT capital in Europe has likely had a counterpart in terms of lower capital deepening and productivity growth, 
it is not a mystery that all sorts of inefficiencies remain hidden in the non-IT manufacturing and services industries, particularly in the EU countries. These inefficiencies are often lumped together under the label "market rigidities" and concern the mode of competition in product, labour and financial markets in Europe, and their potentially damaging effects on the incentives to work, invest and grow. All such impediments may have further been a further drag on productivity growth in Europe, over and above delays in IT adoption and missing leadership in IT production.

Such ideas have been given a precise content within the OECD Growth Project, undertaken in the second half of the 1990s, which has recently given rise, among other publications, to OECD (2003). In this study, the role of product and labour market institutions has been explored using the vast array of aggregate, industry and firm-level data that a number of OECD scholars led by Nicoletti and Scarpetta have put together. Extensive evidence that labour and product market regulation are systematically associated to lower aggregate and industry TFP growth in the OECD countries has been presented in Nicoletti and Scarpetta (2003), while OECD (2003a) had firm-level evidence that the scope for more frequent market experimentation, enabled by the marketfriendly US institutions, may be associated to higher productivity growth. Similar ideas floated around in a few studies undertaken at the European Commission $(2001 ; 2002 ; 2003)$ as well.

The pieces of evidence provided by the OECD may be taken as lending some support to the "IT irrelevance" view for one reason. The OECD studies do not describe delayed IT diffusion as the ultimate cause of the EU productivity slowdown, but rather as one of the manifold manifestation of the inappropriateness of European institutions. Such institutions, by granting excessive protection to the incumbents, may have ended up stifling incentives to both accumulate IT capital as well as to innovate.

A complementary explanation, consistent with the growth accounting evidence for the US and the UK, is proposed by Basu, Fernald, Oulton and Srinivasan (2003). Starting from an adjustment costs model, they point out that declining TFP growth outside the IT-producing industry is precisely to be expected at times of fast technical change. This is because innovation involves costly restructuring and restructuring takes time. Hence, higher IT investment only causes higher costs with no benefits upfront, and thus may result in lower TFP growth in the non-IT part of the economy. In turn, this is reminiscent of the ideas in David (2000) and Greenwood and Jovanovic (1999). If information technologies are pervasive (general-purpose) technologies bound to spread in the economy, this takes time. If the costs of adjusting to a new technology are substantial, along the time interval between their introduction and their effec- 
tive adoption, productivity growth may suffer a shortfall. This would explain why the catching-up in IT diffusion has not raised productivity growth yet.

\section{A numerical rendition of the proposed explanations}

\subsection{The thought experiment}

In what follows, the empirical relevance of each of the three hypotheses briefly described above is numerically evaluated against the yardstick of the best available cross-country productivity data, those employed in O'Mahony and van Ark (2003), downloadable at www.ggdc.nl. This is not explicitly done in their book, which spends instead considerable effort in providing an unusually rich picture of the disaggregated trends of productivity and its components in Europe.

In their data set, real GDP differs somewhat from the published GDP figures in a few respects, mostly related to the treatment of high-tech industries (ISIC Code 30-33). Real GDP for these industries is re-computed separately deflating nominal output and intermediate inputs. Moreover, their price deflators are adjusted for quality for the US. Price deflators for European countries are "harmonized" as in Schreyer (2000), i.e. derived from US deflators corrected for inflation differentials. Given the low inflation differentials between the US and most EU countries over the 1990, this effectively amounts to superimposing a close - but untested - similarity in the price dynamics of high-tech goods between Europe and the US. To avoid that such quality correction translates into an exaggeration of the computed growth rate of overall real value added, real GDP is recalculated through chained weights, i.e. using average weights at time $\mathrm{t}$ and $\mathrm{t}-1$ (Törnqvist indices).

Altogether, these features represent definite improvements over any other data set previously employed in this stream of literature, including those made available by the Groningen Growth and Development Centre (GGDC) itself in the past.

The quantitative evaluation exercise in this section runs as follows. First, labor productivity growth (value added per hour worked) for the business sector is calculated for the two areas: the US and the EU-15 aggregate. The concept of "business sector" employed here is the one borrowed from the OECD, and covers the industries featuring the ISIC Rev. 3 Codes from 1 to 74, except for "Real Estate Activities" (ISIC Rev.3 Code: 70) in the STAN data base. Thus the "business sector" differs from the total economy for "Real estate", "Nonmarket services" and "Social and personal services" are left out. The reasons to leave such services industries out are diverse. Productivity cannot be meaningfully calculated for non-market services and the bulk of the "social and per- 
sonal services" item, for value added is in most cases computed by adding a mark-up onto wages and salaries of the employees for these industries. As far as the "real estate activities" industry is concerned, its exclusion is motivated by the fact that "imputed rent of owner-occupied dwellings" - an item outright unrelated with the business sector - is included with the properly said business activities in the real estate sector under SNA93 for many countries. ${ }^{5}$

As a second step, labor productivity growth is decomposed by industry and, in turn, by industry group, on the output side. As a result, Table 3 can be compiled, where labor productivity growth data for the EU-15 and the US are reported over three distinct periods: 1979-90 (the productivity slowdown period), 1990-95 (the period before the US boom) and 1995-2001 (the period of the US productivity revival). The list of IT-producing industries is based on the OECD classification. In the manufacturing sector, it includes "Office machinery" (ISIC 30), "Insulated wire" (ISIC 313), "Electronic valves and tubes" (ISIC 321), "TLC equipment" (ISIC 322), "Radio and TV receivers" (ISIC 323), "Scientific instruments" (ISIC 331). In the services sector, it includes "Communications" (ISIC 64) and "Computer and related activities" (ISIC 72).

Drafting a list of IT-using industries is more controversial, as discussed below. In VIM (2003a,b), this includes "Clothing" (ISIC 18), "Printing and publishing" (ISIC 22), "Mechanical engineering" (ISIC 29), "Other electrical machinery and apparatus not elsewhere classified" (ISIC 31-313), "Other instruments" (ISIC 33-331), "Building and repairing of ships and boats" (ISIC 351), "Aircraft and spacecraft" (ISIC 352), "Railroad equipment and transport equipment not elsewhere classified" (ISIC 352+359), "Furniture and manufacturing not classified elsewhere" (ISIC 36-37) in the manufacturing sector. In the same papers, the ITusing services industries are "Wholesale trade" (ISIC 51), "Retail trade" (ISIC 52), "Financial intermediation" (ISIC 65-67), "Renting of machinery and equipment" (ISIC 71), "Research and development" (ISIC 73) and "Legal, technical and advertising business services" (ISIC 741-3).

Bearing the data in Table 3 in mind, one can decompose the growth rates of labor productivity of the business sector in its industry group components, draw numerical implications of the three explanations and evaluate the role of IT usage and IT production in determining productivity developments in the US and Europe. This is done in the next sub-sections through the end of this Section.

5 An example of the use of this definition can be found in the 2001 Edition of the OECD STI Scoreboard. 
Table 3

Labor productivity in the EU and the US growth rates and growth contributions ( $\%$ points)

\begin{tabular}{|c|c|c|c|c|c|c|}
\hline & \multicolumn{3}{|c|}{ EU15 } & \multicolumn{3}{|c|}{ US } \\
\hline & $\begin{array}{l}1979- \\
90\end{array}$ & $\begin{array}{l}1990- \\
95\end{array}$ & $\begin{array}{l}1995- \\
01\end{array}$ & $\begin{array}{l}1979- \\
90\end{array}$ & $\begin{array}{l}1990- \\
95\end{array}$ & $\begin{array}{l}1995- \\
01\end{array}$ \\
\hline $\begin{array}{l}\text { Labor productivity } \\
\text { growth } \\
\text { Business sector }\end{array}$ & 1.61 & 1.59 & 1.43 & 0.97 & 1.07 & 2.07 \\
\hline \multicolumn{7}{|c|}{ Contributions to labor productivity growth from: } \\
\hline IT producers & .34 & .24 & .49 & .26 & .43 & .68 \\
\hline $\begin{array}{l}\text { IT producers, manufactur- } \\
\text { ing }\end{array}$ & .14 & .03 & .09 & .15 & .26 & .43 \\
\hline IT users (broad definition) & .71 & 63 & .58 & .44 & .22 & 1.23 \\
\hline $\begin{array}{l}\text { Non-IT industries (broad } \\
\text { definition of IT users) }\end{array}$ & .56 & .72 & .36 & .26 & .43 & .16 \\
\hline $\begin{array}{l}\text { IT users (narrow defini- } \\
\text { tion) }\end{array}$ & .58 & .52 & .51 & .23 & .20 & .84 \\
\hline $\begin{array}{l}\text { Non-IT industries (narrow } \\
\text { definition of IT users) }\end{array}$ & .69 & .83 & .42 & .47 & .44 & .55 \\
\hline
\end{tabular}

Notes: Labor productivity is measured as value added per hour worked. The reported growth rate of labor productivity for the business sector is the sum of the various industry groups' growth contributions. In turn, each of the industry contribution is the product of the growth rate of labor productivity of each industry times its value added share at the initial time in each sub-period. Hence, the reported growth contributions only include the so called "pure productivity growth" effect (see Nordhaus 2002a; 2002b). - Data refer to the business sector, not to the total economy. "Business sector" includes all the industries in the economy except for "Real estate", "Social and personal services" and "Non-market services". The industry codes are: ISIC Rev.3: 1-74, excluding 70 (Real Estate Activities). -The list of the IT-using industries is as in van Ark, Inklaar and McGuckin (VIM 2003a; 2003b).

Source: Own calculations from O’Mahony and van Ark (2003, 111 ff.).

\subsection{The explanatory power of the IT production view}

\section{Numerical evaluation}

The IT production view is conveniently numerically evaluated first, in both its "US over time" and "EU vs. US" variants. First, to test the explanatory power of the IT production view for the US economy over time, one can use the data in 
Table 3 and raise the Gordon question: how much of the total labor productivity gain in the US economy is accounted for by the change in the growth contribution of IT-producing manufacturing? Second, but more relevant here, one may want to compare the relative productivity performances of the EU and the US over time and ask how much of the EU-US gap in the changes of productivity growth rates is explained by gaps in the contributions from overall IT production. The figures in Table 4 provide the elements to answer both questions.

Table 4

Evaluating the "IT production" hypothesis

\begin{tabular}{|l|ll|}
\hline \multicolumn{3}{|l|}{ Business sector, percentage points } \\
\hline & $\begin{array}{l}\text { US } \\
(1995-01)-(1990-95)\end{array}$ & $\begin{array}{l}\text { US-EU } \\
\text { (1995-01)-(1990-95) }\end{array}$ \\
$\Delta$ (Labor productivity) & $\begin{array}{l}\text { (1.00 } \\
(=2.07-1.07)\end{array}$ & +1.16 \\
& & {$[=(2.07-1.07)-(1.43-1.59)]$} \\
$\Delta$ (Labor productivity), IT & +.25 & +.00 \\
producers & $(=.68-.43)$ & {$[=(.68-.43)-(.49-.24)]$} \\
& & \\
$\Delta$ (Labor productivity), IT & +.17 & +.11 \\
producers, manufacturing & $(=.43-.26)$ & {$[=(.43-.26)-(.09-.03)]$} \\
\hline
\end{tabular}

Source: Own calculations from data in Table 3.

The "US over time" variant of the IT production view is verified by computing what fraction of the period change in the growth rate of labor productivity between 1990-95 and 1995-2001 can be attributed to IT production. The contribution of the IT-producing industries to the productivity acceleration in the US economy stemming from the pure productivity effect (see Nordhaus 2002a; $2002 b$ ) is about one fourth of the total acceleration. The growth contribution to labor productivity of IT-producing industries rose from .43 percentage points in $1990-95$ to .68 in $1995-2001$, hence by about .25 points. This is exactly one fourth of the total increase in labor productivity growth of 1.00 percentage points experienced in the US economy in 1995-2001 with respect to 1990-95. Consistent with the Gordon hypothesis, most of this much (two thirds of it) is due to the productivity acceleration in the manufacturing industries producing IT durable goods.

The IT production view is therefore not devoid of explanatory power when looking at the sources of the US productivity revival. The overall growth con- 
tribution from IT producers is instead essentially zero when one comes to explain the EU-US gap in the changes of productivity growth over time. Faced with a total of 1.16 p.p. to be accounted for - the combination of faster growth of about 1 percent in the US and lower growth of about .20 of a percentage point in Europe, IT production contributes for nothing. This is because the growth contributions from IT production went up by the same amount in the US and in the EU ( +.25 percentage points). Interestingly, most of the increased productivity contribution of IT production was due to the industries producing IT services (such as TLC services) and not to the manufacturing ones, as was the case in the US.

Where do such different results come from? Marked changes in growth rates make the bulk of the result. The acceleration to double-digit growth rates of labor productivity in high-tech industries, though, was likely a worldwide phenomenon and occurred in both the US and the EU-15. Hence this acceleration effect, although more pronounced in the United States, does not account for a sizable share of the cross-country US-EU gap in the changes of productivity growth, but only for a tiny part of it. At the same time, however, it was a nonnegligible part of the US productivity acceleration over time. This well accords with previous findings, in particular in van Ark, Inklaar and McGuckin (2003a).

\section{Discussion}

A qualifier to these conclusions is warranted here, though. As recalled above in Section 4.1, the national accounting price deflators for high-tech goods are not adjusted for quality changes outside the US and a handful of other OECD countries, including France, but not including Germany, Italy, the UK, Spain and the Netherlands. Therefore, the currently available national accounting data, such as those currently embodied in the OECD STAN data base, do not systematically reflect such quality matters. This has led the GGDC researchers and their colleagues to construct alternative price deflators for high-tech goods from Schreyer's "harmonization assumption" (see Section 4.1). In turn, this amounted to assuming that the dynamics of the prices of high-tech goods in Europe is essentially driven by the dynamics of US prices, except for an overall inflation correction.

In their papers, the GGDC scholars repeatedly reported that such a correction does not make a big difference for the behavior of aggregate productivity. This does not, however, seemingly apply to high-tech industries, whose estimated productivity growth may be raised substantially by this correction. To learn about the order of magnitude of this possible bias, it is instructive to take a look at Table 5 where the productivity growth rates of the computer industry (ISIC Rev.3 Code 30 in STAN) in Germany and France are reported. Such 
growth rates are calculated using two data sets: the publicly available data from the OECD STAN data base and the data in the O'Mahony-vanArk data set. Differences in the computed growth rates are staggering. Not only are computed growth rates sharply different in the two cases, but also the direction of the acceleration is not the same across data sets at least for France. Given a value added share of about 0.35 percentage points in both countries, the hightech contribution to accelerating growth estimated through STAN data amounts to .01 percentage points for Germany and negative .02 percentage points for France. These are very small figures indeed. It instead adds up to much bigger figures (.15 for Germany and .07 for France) when the GGDC data are employed. This indicates that using one price deflator or the other does make a big difference. Before coming to a definite conclusion about the unimportance of IT production as a source of the EU-US gap in the late 1990s, one would like to be reassured that this result is not crucially measurementdriven. It is impossible to be less conjectural at this stage, for the O'Mahonyvan Ark data set is the result of an impressive effort also inclusive of substantial data filling, which often prevents pair-wise data comparisons from different data sources.

Table 5

Comparing labor productivity growth in the computer industries from different data sets

\begin{tabular}{|l|cc|}
\hline \multicolumn{2}{|l|}{ Value added per employed person. Percentage points } & \\
\multicolumn{2}{|l|}{ O'Mahony-van Ark } & STAN \\
\hline Office machinery et al. (ISIC rev.3 code: 30) & & \\
Germany & & \\
1991-95 & 31.7 & 11.1 \\
1995-00 & 75.2 & 15.2 \\
1995-00 minus 1991-95 & +43.5 & +4.1 \\
France & & \\
1991-95 & 29.0 & 28.7 \\
1995-00 & 48.6 & 21.4 \\
1995-00 minus 1991-95 & +19.4 & -7.3 \\
\hline
\end{tabular}

Source: Own calculations from O'Mahony and van Ark (2003) and STAN. 


\section{Summing up}

The IT production view does not strike the eye as a promising explanation of the EU-US growth gap. This result is clearly affected by the treatment of IT goods prices, though, in a direction still hard to assess with the currently available information.

\subsection{The IT usage view}

In this section, the explanatory power of the IT usage hypothesis is quantified. The extent to which such results are sensitive to how industry classification issues are resolved is also discussed.

\section{Replicating previous results}

The IT usage view can be easily recovered from the data reported in Table 6 in its "US over time" and "EU vs. US" variants as well. The "US over time" variant is verified by computing what fraction of the period change in the growth rate of labor productivity between 1990-95 and 1995-2001 is to attribute to IT usage. On the output side, the increased growth contribution from IT users is 1.01 percentage points (from .22 percent in 1990-95 to 1.23 percent in 1995-01). In practice: 100 percent of the total increase of one percentage point.

Table 6

Evaluating the "IT usage" hypothesis

\begin{tabular}{|c|c|c|}
\hline \multicolumn{3}{|c|}{ Business sector, percentage points } \\
\hline & $\begin{array}{l}\text { US } \\
(1995-01)-(1990-95)\end{array}$ & $\begin{array}{l}\text { US-EU } \\
(1995-01)-(1990-95)\end{array}$ \\
\hline$\Delta$ (Labor productivity) & $\begin{array}{l}+1.00 \\
(=2.07-1.07)\end{array}$ & $\begin{array}{l}+1.16 \\
{[=(2.07-1.07)-(1.43-1.59)]}\end{array}$ \\
\hline \multicolumn{3}{|c|}{ (a) Broad definition of IT-using industries } \\
\hline $\begin{array}{l}\Delta \text { (Labor productivity), IT } \\
\text { users }\end{array}$ & $\begin{array}{l}+1.01 \\
(=1.23-.22)\end{array}$ & $\begin{array}{l}+1.06 \\
{[=(1.23-.22)-(0.58-0.63)]}\end{array}$ \\
\hline \multicolumn{3}{|c|}{ (b) Narrow definition of IT-using industries } \\
\hline $\begin{array}{l}\Delta \text { (Labor productivity), IT } \\
\text { users }\end{array}$ & \begin{tabular}{|l}
+.64 \\
$(=.84-.20)$ \\
\end{tabular} & $\begin{array}{l}+.65 \\
{[=(.84-.20)-(.51-.52)]}\end{array}$ \\
\hline
\end{tabular}

Source: Own calculations from data in Table 3. 
How about the "EU vs. US" variant of the IT usage view, due to van Ark, Inklaar and McGuckin? Again, the VIM result is easily recovered. The variables to look at are those in double-differences. As mentioned in the introductory section, it is not the European slowdown in productivity growth as such to be explained, but rather its relative slowdown vis-à-vis the acceleration in the US productivity growth. The dependent variable to look at is thus the difference between the period change in the US variable of interest and the same period variation for the EU-15 variable of interest. This is equal to 1.16 percentage points for the growth rate of labor productivity of the business sector, i.e. the difference between the US acceleration $(+1.00$ percentage points) and the same period change in the EU (-0.16 percentage points, as a result of a slight growth slowdown from 1.59 percent in 1990-95 to 1.43 percent in 1995-2001).

How much of this double difference is explained by IT usage? Quite a bit, as reported in the rightmost part of Table 6 . When the decomposition is done on the output side, the growth contribution from IT-using industries is about 1.05 p.p. or roughly 91 percent of the total.

Hence, irrespective of whether one looks at the US or at the EU compared to the US, there is a strong sense in which the IT usage view first-hand accurately explains virtually all of what is meant to explain, namely the US productivity revival or the relative productivity slowdown of the EU (the EU-15).

\section{Discussion}

As mentioned in Section 3.1, the IT usage view crucially rests on the identification of a subset of industries as "IT users". Classifying industries according to their IT intensity is a contentious issue, though, for three main reasons:

1. a criterion must be chosen, which may be based on one or more variables. A problem manifests itself here in case the industry ranking changes depending on which variable is chosen as a criterion;

2. for any given criterion, a threshold must be chosen so as to separate the group of the IT-users from the group of the non-IT users. The problem here is the unavoidable arbitrariness of the chosen threshold.

3. For any given criterion and threshold, an industry may turn out to be IT-intensive in one country and non-IT-intensive in another country, depending on such things as factor prices and endowments.

In his 2002 paper, Stiroh identified as IT users those industries where the IT share of total capital services was in the top 50 percent ranking in 1995, hence above the median of the distribution An alternative, but not less plausible, 
threshold might be to label "IT users" those industries with values of the criterion above the average for the whole economy.

VIM (2003a) nicely raised question (3), appropriately reporting national accounting data for the shares of IT investment over total investment for the US, France, Germany, the Netherlands and the UK in one of their Appendix Tables (Table A.2), coming to the conclusion that cross-country differences are not too serious. The extent to which the IT content classification of industries is an issue is perhaps more easily appreciated by looking at the implications of adopting various criterion thresholds, within the data set currently used here to evaluate the IT usage hypothesis.

As discussed in Stiroh (2002), the share of IT capital services in value added is reckoned to be the best indicator of IT intensity, for it identifies as IT intensive those industries tangibly spending money in IT and being successful in reallocating inputs towards high-tech assets. Inklaar, O’Mahony and Timmer (2003) report the values of IT capital services shares in value added, averaged over 1979-95 and 1995-2000, for 26 industries for the US, their EU-4 aggregate and the four individual EU countries (see Table B.15 and B.16 in their paper). The need to choose an indicator relatively exogenous to the productivity revival suggests that $1995-00$ data should be prudentially left aside. A classification employed to draw inference about the features of the after-1995 productivity revival should in fact be based on data before the productivity revival has actually started. Hence one is left with the value added shares of IT capital services over 1979-95 as the relevant classification criterion.

Based on such 1979-95 rankings, retail ranks 9th and 10th, respectively in the US and the EU-4, hence well within the 50 percent median threshold chosen by Stiroh. Yet, thinking it through, one may wonder whether such a threshold is a really sensible yardstick. In fact, it turns out that, while the Stiroh criterion classifies retail among the IT-using industries, retail was actually using less IT capital (and therefore generating less IT capital services) than the average industry in the whole US economy (2.79 against 3.37 percentage points). The same thing applies to the EU-4 (2.10 against 2.49) and to three (Germany, France, the Netherlands) of the individual EU countries for which data are available. The UK is the only exception where retail trade exhibits aboveaverage IT intensity. This is again contradicted, however, by the IT intensity data in the careful study of Basu, Fernald, Oulton and Srinivasan (2003, Table 10), where the 1990 value added shares of IT goods in retail trade are reportedly lower than the average of the UK economy for all the IT goods, as well as for computers and software, although not so for communication equipment.

Hence, depending on the specific threshold chosen, a crucial industry such as retail - accounting for the bulk of the productivity gains for Stiroh and one of 
the three explaining the bulk of the EU-US productivity growth gap - may no longer be classified among the IT users and be assigned instead to the group of the non-IT industries.

Furthermore, this problem is not restricted to retail. Careful scrutiny of the list of the industries classified among the IT intensive industries by Inklaar, O'Mahony and Timmer gives very similar results. "Clothing", "Paper and printing", "furniture equipment not elsewhere classified" and, more markedly than others, "Transport equipment" are all manufacturing industries classified among the IT intensive industries which feature below-average IT capital services share of value added in the US and the EU-4 in 1979-95.

One may thus legitimately wonder what is left of the explanatory power of the IT usage view when a different classification criterion is employed instead. In what follows, to exemplify, "retail" and "transport equipment" are assigned to the group of the non-IT industries.

The basic results from such a reclassification are reported in the lower panel (panel $b$ ) in Table 6 . Although not totally overturned, their numerical extent looks somewhat different from those seen above. The remaining IT-using industries still play a crucial role, but only explains, respectively, 64 percent and 55 percent of the total acceleration (while the explained fraction of the observed productivity acceleration was some 100 percent or 90 percent in the baseline VIM-based case).

In conclusion, the explanatory power of the IT usage view is therefore clearly weakened under a different, but equally (or even more) plausible than the one employed by Stiroh and VIM in their papers.

\subsection{IT irrelevance}

The explanatory power of the IT irrelevance view strictly depends on how restrictive the criteria for classifying industries within or outside the group of the IT-users. As shown in Table 7, the bottom line here is that, in the baseline case where retail and transport equipment are IT-using industries, the overall contribution of non-IT industries to the understanding of the EU productivity slowdown is even negative for the US and rather small (some 5 percent of the total) when the US-EU growth gap is to be explained. This is because the productivity growth slowdown occurring in the EU-15 has had a close counterpart in the US as well. In particular, the non-IT manufacturing has suffered from a sharp productivity shortfall in both areas in 1995-2001. 
Table 7

Evaluating the "IT irrelevance" hypothesis

\begin{tabular}{|l|ll|}
\hline \multicolumn{2}{|l|}{ Business sector, percentage points } \\
\hline & $\begin{array}{l}\text { US } \\
(1995-01)-(1990-95)\end{array}$ & $\begin{array}{l}\text { US-EU } \\
(1995-01)-(1990-95)\end{array}$ \\
$\Delta$ (Labor productivity) & $\begin{array}{l}+1.00 \\
(=2.07-1.07)\end{array}$ & +1.16 \\
& {$[=(2.07-1.07)-(1.43-1.59)]$} \\
(a) Broad definition of IT-using industries & \\
$\begin{array}{l}\Delta \text { (Labor productivity), } \\
\text { non-IT industries }\end{array}$ & +.27 \\
$\begin{array}{l}\text { (b) Narrow definition of IT- }=.16-.43) \\
\Delta \text { (Labor productivity }),\end{array}$ & $\begin{array}{l}+.11 \\
(=.55-.44)\end{array}$ & $+.16-.43)-(.36-.72)]$ \\
non-IT industries & +.52 \\
\hline
\end{tabular}

Source: Own calculations from data in Table 3.

Things change quite radically, however, when the baseline case is amended and "retail" and "production of transport equipment" are classified among the non-IT industries. If this is done, the EU-US gap in the changes of productivity growth rates is accounted for by non-IT industries to a major extent (.52 percentage points, about 45 percent of the total 1.16 percentage points).

\section{Summing up}

To sum up, simple back-of-the-envelope calculations, using the latest version of the same data set employed by VIM (2003a; 2003b), clearly shows strengths and weaknesses of the IT usage view as an explanation of the EU productivity slowdown.

If one adopts the same median threshold as in Stiroh and VIM, the IT usage hypothesis is an iron hypothesis: it explains - in an accounting sense - almost everything. If, however, labels carry a meaning, industries using IT less than the average of the whole economy should not perhaps be grouped among the IT-intensive users. Conclusions on the explanatory power of the IT usage hypothesis should therefore be qualified accordingly: it explains about 55 percent of the total EU-US gap in the period changes of productivity growth. This is indeed a large part of it, but by no means the whole of the gap, the rest of which is explained by the productivity slowdown in non-IT industries. 


\section{Conclusions}

In this paper, an accounting evaluation of three potential explanations of the productivity slowdown in Europe has been offered. Most of the attention has been devoted to show the controversial quantitative basis of the so called IT usage hypothesis. Depending on how specific industries are assigned to one group or another, the conclusions on the relative importance and explanatory power of each explanation may change to a non-negligible extent.

Is there a policy message attached to such findings? Yes, at least one. If one thinks that the IT usage hypothesis is in the background of the recipes stated in the Lisbon strategy, the results reported here should be taken to imply that spreading IT around Europe will not necessarily make Europe grow faster, unless such IT-friendly policies are accompanied by other non-IT centered policies aimed at raising productivity even in the non-IT part of the economy.

In this respect, the slowdown in the growth rate of labor productivity in nondurable manufacturing - the area of the economy where IT diffusion is perhaps less profound - should be considered worrisome in two respects. First, although declining as a share of value added everywhere, the manufacturing share of value added is bigger than in the US (19 percent of EU total value added against 14 percent in the US). Hence, the manufacturing decline is more important for Europe than the same phenomenon for the US. Moreover, most EU countries still entertain their revealed comparative advantage in mature manufacturing industries, producing non-durable or medium-high tech manufacturing goods. Hence, declining productivity growth in such industries is a signal that some change is probably needed there, such as changes in labor or product market legislation.

Which change is involved is not transparent. Two views confront each other. Europe's labor market reforms in the second part of the 1990s - although introduced in bits and pieces - effectively encouraged the hiring of unskilled parttime workers. The evidence (see e.g. European Commission 2003) shows that such new entrants in the labor market, given their low human capital endowment, found themselves employed in traditional industries. If productivity growth has been hampered by the entry of unskilled workers in the labor market, which drove down the equilibrium capital-labor ratio, this should not necessarily be regarded as a permanently negative feature. It might simply be the other side of the coin of the increased employment rate of the last five years. In other words, it might just be transitional, and perhaps Governments should not be overly pessimistic about Europe's growth prospects.

The pessimistic view is simpler and would instead point to insufficient reallocation of workers away from manufacturing into newer, more dynamic, indus- 
tries as the main source of the declining productivity growth in that sector. This would suggest that Governments have indeed to do something, namely continue along the undertaken path of market reform in the goods and labor markets, perhaps broadening their scope and enlarging their extent.

Understanding whether optimists or pessimists are right should rank high in the research agenda in the near future.

\section{References}

Ark, B. van, R. Inklaar and R.H. McGuckin (2003a), "Changing Gear Productivity, ICT and Service Industries: Europe and the United States", in J.F. Christensen and P. Maskell (eds.), The Industrial Dynamics of the Digital Economy, Edward Elgar, Cheltenham.

Ark, B. van, R. Inklaar and R.H. McGuckin (2003b), "ICT and Productivity in Europe and the United States: Where Do the Differences Come from?", CESifo Economic Studies 49(3), 295-318.

Ark, B. van, J.Melka, N.Mulder, M.Timmer and G. Ypma (2002), ICT Investment and Growth Accounts for the European Union, 1980-2000, Report to the European Commission, DG Economics and Finance, September.

Basu, S., J.G. Fernald, N. Oulton and S.Srinivasan (2003), "The Case of the Missing Productivity Growth or: Why Has Productivity Accelerated in the United States but not the United Kingdom?", NBER Macroeconomics Annual.

Blanchard, O. (2003), "The Economic Future of Europe", mimeo, MIT, Journal of Economic Perspectives, forthcoming.

Colecchia, A. and P. Schreyer (2002), "ICT Investment and Economic Growth in the 1990s: Is the United States a Unique Case? A Comparative Study of Nine OECD Countries", Review of Economic Dynamics 5, 408-442.

Daveri, F. (2000), "Is Growth an ICT-Story in Europe too?", IGIER Working Paper 168, July, downloadable at www.igier.uni-bocconi.it/daveri.

Daveri, F. (2002), "The New Economy in Europe, 1992-2001", Oxford Review of Economic Policy 18, 345-362.

Daveri, F. and O. Silva (2004), "Not only Nokia: What Finland Can Tell Us about New Economy Growth", Economic Policy (38), 117-163.

European Commission (2003), "Drivers of Productivity Growth. An Economywide and Industry Level Perspective", ch.2, in "The EU Economy 2003 Re- 
view", Directorate-General for Economic and Financial Affairs, European Economy 74(6), 64-118.

Gordon, R.J (2000), "Does the "New Economy" Measure up to the Great Inventions of the Past?", Journal of Economic Perspectives 14, 49-74.

Gordon, R.J. (2003a), "Hi-tech Innovation and Productivity Growth: Does Supply Create Its own Demand?”, NBER Working paper \#9437, January.

Gordon, R.J. (2003b), "Five Puzzles in the Behavior of Productivity, Investment, and Innovation", mimeo, paper prepared for the World Economic Forum, September.

Inklaar, R., M. O'Mahony and M.Timmer (2003), “ICT and Europe's Productivity Performance Industry-level Growth Accounting Comparisons with the United States", Groningen Growth and Development Center, Research Memorandum GD-68, December.

Jorgenson, D.W., F.M. Gollop and B.M. Fraumeni (1987), Productivity and U.S. Economic Growth, Harvard University Press, Cambridge.

Jorgenson, D.W., M.S. Ho and K.J. Stiroh (2003), "Lessons for Europe from the U.S. Growth Resurgence", CESifo Economic Studies 49(1), 27-47.

Jorgenson, D.W. and K.J. Stiroh (2000), "Raising the Speed Limit: U.S. Economic Growth in the Information Age", Brookings Papers on Economic Activity 31,125-211.

McKinsey Global Institute (1997), "France and Germany”, mimeo, October.

McKinsey Global Institute (2002), "Reaching high productivity growth in France and Germany", mimeo, October.

Nordhaus, W.D. (2002a), "Productivity growth and the new economy", Brooking Papers on Economic Activity 33, 1-67.

Nordhaus, W.D. (2002b), "Alternative methods for measuring productivity growth including approaches when output is measured with chain indexes", mimeo, June 24.

OECD (2003), ICT and economic growth: evidence from OECD countries, sectors and firms, Paris.

Oliner, S.D. and D.E. Sichel (2000), "The resurgence of growth in the late 1990s: is information technology the story?", Journal of Economic Perspectives 14, 3-32.

O'Mahony, M. and B. van Ark (eds.) (2003), EU productivity and competitiveness: an industry perspective. Can Europe resume the catching-up process?, European Commission, DG Enterprise, Luxembourg: Office for the Official Publications of the European Communities. 
Schreyer, P. (2000), "The contribution of information and communication technology to output growth: a study of the G7 countries", OECD, DSTI/DOC(2000)2, March.

Stiroh, K.J. (2002), "Information technology and the US productivity revival", American Economic Review (December), 1559-1576.

Timmer, M., G. Ypma and B. van Ark (2003), "IT in the European Union: driving productivity divergence", Groningen Growth and Development Center, Research Memorandum GD-67, October, www.eco.rug.nl/ggdc/pub/.

Triplett, J. and B. Bosworth (2002), "Baumol's disease has been cured: IT and multifactor productivity in U.S. services industries", mimeo, the Brookings Institution, September. 
